\title{
Use of Foods Based on Bee Drone Brood: Their Sensory and Microbiological Evaluation and Mineral Composition
}

\author{
Marie Borkovcová ${ }^{1}$, Jiř́i Mlček ${ }^{1}\left(\mathbb{D}\right.$, Anna Adámková ${ }^{1, *(1)}$, Martin Adámek ${ }^{2,3}$, Martina Bednářová ${ }^{4}$, \\ Zuzana Musilováa ${ }^{1,5}$ and Veronika Ševčíková ${ }^{1}$ (D)
}

Citation: Borkovcová, M.; Mlček, J.; Adámková, A.; Adámek, M.;

Bednářová, M.; Musilová, Z.;

Ševčíková, V. Use of Foods Based on Bee Drone Brood: Their Sensory and Microbiological Evaluation and Mineral Composition. Sustainability 2022, 14, 2814. https://doi.org/ $10.3390 /$ su14052814

Academic Editors: Ewelina Zielińska, Urszula Pankiewicz, Monika Sujka and Marc A. Rosen

Received: 28 October 2021

Accepted: 25 February 2022

Published: 28 February 2022

Publisher's Note: MDPI stays neutral with regard to jurisdictional claims in published maps and institutional affiliations.

Copyright: (C) 2022 by the authors. Licensee MDPI, Basel, Switzerland. This article is an open access article distributed under the terms and conditions of the Creative Commons Attribution (CC BY) license (https:// creativecommons.org/licenses/by/ $4.0 /)$.
1 Department of Food Analysis and Chemistry, Faculty of Technology, Tomas Bata University in Zlin, Vavreckova 275, 76001 Zlin, Czech Republic; edible.insects@gmail.com (M.B.); mlcek@ft.utb.cz (J.M.); zuzana.kolatkova@gmail.com (Z.M.); v2_sevcikova@utb.cz (V.Š.)

2 Department of Physics and Materials Engineering, Faculty of Technology, Tomas Bata University in Zlin, Vavreckova 275, 76001 Zlin, Czech Republic; m2adamek@utb.cz

3 Department of Microelectronics, Faculty of Electrical Engineering and Communication, Brno University of Technology, Technicka 3058/10, 61600 Brno, Czech Republic

4 Department of Information Technology, Mendel University in Brno, Zemedelska 1, 61300 Brno, Czech Republic; bednarova@mendelu.cz

5 Department of Food Technology, Mendel University in Brno, Zemedelska 1, 61300 Brno, Czech Republic

* Correspondence: aadamkova@utb.cz

\begin{abstract}
The aim of the work was to evaluate the safety of bee drone brood in terms of the risk of possible contamination with heavy metals, microbial contamination, and sensory acceptability. Bee drone brood dried at a temperature of $80{ }^{\circ} \mathrm{C}$ in a hot air oven (DBO) and lyophilized drone brood (DBL) were used. Sensory evaluation was performed on an oatmeal ball (O-B) and drone brood ball (DBO-B). For the determination of the minerals and other elements in DBO, spectrometric analysis was used. The content was as follows: Fe $60.87 \mu \mathrm{g} / \mathrm{g}, \mathrm{Cu} 54.83 \mu \mathrm{g} / \mathrm{g}, \mathrm{Zn} 257 \mu \mathrm{g} / \mathrm{g}, \mathrm{Ag}$ $82.7 \mu \mathrm{g} / \mathrm{g}$, Pb $2.1 \mu \mathrm{g} / \mathrm{g}$, Au $1.2 \mu \mathrm{g} / \mathrm{g}$, Ca $1336 \mu \mathrm{g} / \mathrm{g}$, Sr $3.13 \mu \mathrm{g} / \mathrm{g}, \mathrm{Zr} 1.67 \mu \mathrm{g} / \mathrm{g}$, Bi $3.87 \mu \mathrm{g} / \mathrm{g}, \mathrm{Br}$ $1.95 \mu \mathrm{g} / \mathrm{g}$. The detected content of lead in dry matter $(2.1 \mu \mathrm{g} / \mathrm{g})$ was high above the limit set for crustaceans $(0.4 \mu \mathrm{g} / \mathrm{g})$. By comparing microbial assay values, no statistically significant difference between freshly dried DBO and dried DBO after a month of storage was detected. Bee drone brood contains microbes far below the legal limits and it is a good source of calcium, iron, and zinc. Except for the juiciness, consumers rated O-B better than DBO-B. A statistically significant difference $(p<0.05)$ was found only in taste.
\end{abstract}

Keywords: bee brood; drone brood; sensory analysis; minerals; microbiological analysis

\section{Introduction}

Due to the ever-increasing world population, attempts are being made to expand the area of arable land, which competes with both urbanization pressure and the need to conserve natural habitats. Animal production today also consumes more protein (77 million tons) than it can produce for human consumption (58 million tons) [1]. Insects can be easily bred in large numbers on a minimum space, compared with conventional cattle. With significantly higher fertility and shorter generation times, insects reproduce very quickly and have an excellent nutritional composition [2].

Edible insects and insect products are defined in a European regulation as a novel food. Regulation (EU) 2015/2283 of the European Parliament and of the Council was issued on 1 January 2018 that insects meet the definition of a novel food. From the same date, it is therefore possible to place insects on the entire European market on the basis of Article 35 of EU Regulation 2015/2283.

Honey bee drone brood (DB) (larvae, pupae, and eggs of honey bee Apis mellifera) is a promising bee product, mainly due to its high vitamin content such as vitamin A 
and vitamin $\mathrm{D}$, the presence of which is even higher than that found in fish oil [3,4]. Bee drone brood also contains a significant amount of phosphorus, magnesium, calcium, and potassium [5,6]. Ghosh et al. [7] reported a calcium content of $849 \mu \mathrm{g} / \mathrm{g}$ in larvae dry matter and $970 \mu \mathrm{g} / \mathrm{g}$ in pupae and iron content of $133 \mu \mathrm{g} / \mathrm{g}$ in larvae and $153 \mu \mathrm{g} / \mathrm{g}$ in pupae. Zinc values were $116 \mu \mathrm{g} / \mathrm{g}$ for larvae and $117 \mu \mathrm{g} / \mathrm{g}$ for pupae.

However, with increasing heavy metal environmental pollution, the possibility of heavy metal accumulation in bee drone brood is above a safe level. Therefore, it is necessary to monitor their level in terms of food safety and human health.

The percentage of protein is the same as that for conventional meat, and brood protein is a good source of most basic amino acids [4,8]. Bee drone brood contains an average of $40 \mathrm{~g} / 100 \mathrm{~g}$ proteins in DM. The dominant amino acid is leucine. Lysine, which has gained attention as a limiting amino acid for cereals, is the second most abundant amino acid. Valine is the third most abundant amino acid $[9,10]$. Furthermore, the usability of essential amino acids is high, and the ratio between essential and non-essential amino acids is suitable for humans [7]. Since Apis mellifera belongs to an insect group that is unable to convert plant sterols to animal sterols, it does not pose a risk in terms of high cholesterol [11].

In a social context, the interest in the use of bee drone brood corresponds to current trends in the environmental field, where ever-higher demands are placed on labor productivity, waste utilization, and social standards. The use of living ecological systems and cycles, including their support and imitation, is therefore increasingly required in agricultural and food production. Bee drone brood (the larvae of male honey bees) are bred primarily for the purpose of fertilizing the queen bee and preserving the offspring. Furthermore, many beekeepers have established the breeding of bee drone brood as a biological means (trap) to control the population of the bee mite (Varroa destruktor), which causes bee diseases by Varroasis apium. While doing so, the bee drone brood is removed from the hive before the end of the developmental cycle [12]. Bee drone brood removal is also used as an anti-swarm precaution [12]. The removed bee drone brood becomes waste, which can be utilized as raw food material, and it can bring additional income to beekeepers and thus increase the efficiency of their breeding and support sustainable beekeeping [13].

Because the honey bee is the only domesticated species of insect in the Czech Republic and beekeeping is a successful insect breeding system, the use of drone brood in the food industry can be beneficial in terms of its nutritional composition [14-17].

Microbial safety, which is generally important for food, must be monitored even better for food from insects and insect products. The EFSA Scientific Committee presents potential biological and chemical hazards as well as allergenicity and environmental hazards associated with farmed insects used as food [18]. In the work of Stoops et al. [19], high levels of Enterobacteriaceae were found in fresh samples of mealworm (Tenebrio molitor) and migratory locust (Locusta migratoria migratorioides). The study by Klunder et al. [20], in a laboratory experiment with mealworm and house cricket (Acheta domesticus), found that cooking eliminates the vegetative forms of Enterobacteriaceae for several minutes, but spores survive and germinate under appropriate conditions. In the species mealworm, superworm (Zophobas morio), waxworm (Galleria mellonella), butterworm (Chilecomadia moorei), and house cricket, neither Listeria monocytogenes nor Salmonella spp. were detected.

Not only is nutritional value important for food evaluation, but food must also be safe and should taste good. The aim of the work was to evaluate the safety of food based on drone brood in terms of the risk of possible contamination with heavy metals and microbial contamination as well as the sensory acceptability of these foods by consumers. The following hypotheses were established to meet the objectives:

(a) Drone brood is safe from a microbial and elemental point of view for the production of DB-based foods (the measured values are below the safety limits);

(b) In terms of sensory properties, DB-based products are acceptable to consumers. 


\section{Materials and Methods}

\subsection{Collection and Conservation of Bee Drone Brood}

The bee drone brood processing procedure is shown in Figure 1 and described below. Honey bee drone brood was harvested from hives at several habitats in the town of Opava (Czech Republic) during the period from early May to early June 2016. Twenty-eight hives were used, and DB tubing frames of different maturity were obtained. From one frame, the larvae, pupae, or eggs of bee drones were obtained. This ratio was approximately $70 \%$ larvae and $30 \%$ pupae. The main reason for the preference of the larvae was because it is difficult to remove the brood from the pupa. The DB samples were frozen $\left(-18^{\circ} \mathrm{C}\right)$ after harvesting and then processed by drying in a hot air oven (DBO).

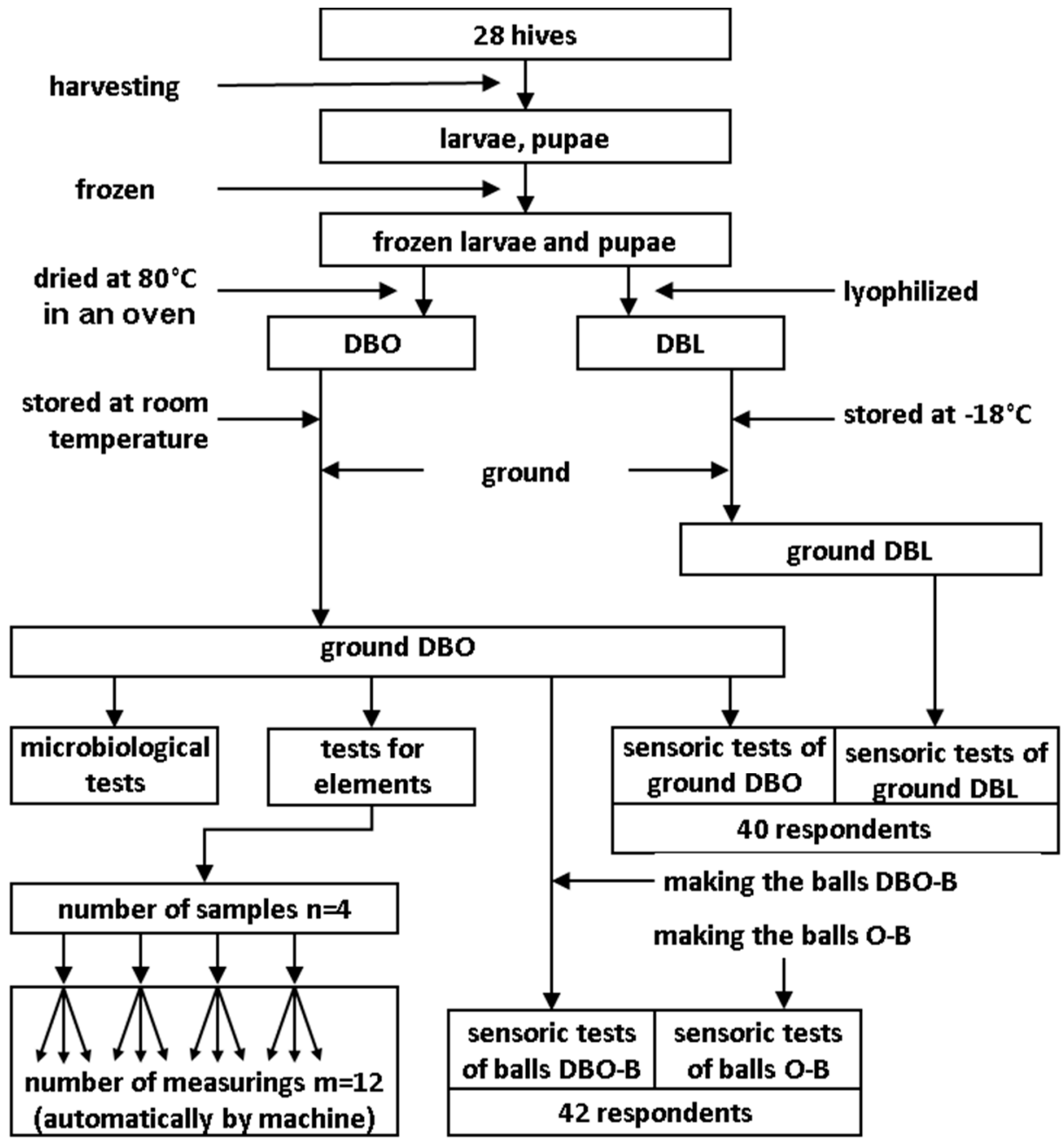

Figure 1. The bee drone brood processing procedure.

\subsubsection{Drying}

Freeze-preserved DB was first left to thaw at room temperature and subsequently homogenized. A thin layer of the homogenized DB was evenly spread on a sheet of baking paper and then placed in a hot-air oven (UF55, Memmert GmbH + Co.KG, Buchenbach, Germany). DB was preserved by drying in an oven at $80^{\circ} \mathrm{C}$ until it did not adhere to a finger (approximately $4 \mathrm{~h}$ ). While still warm, the layer was scraped off from the baking paper and again homogenized in a kitchen mixer. The groundmass was evenly distributed over the sheet and placed in an $80{ }^{\circ} \mathrm{C}$ oven for one hour to dry out. The dried DB was pulled out of the oven, left to cool down, and subsequently stored in a plastic box at room temperature. A temperature of $80^{\circ} \mathrm{C}$ was chosen from the availability of temperatures mentioned in Ghosh et al. [7], where the temperature was set at $100{ }^{\circ} \mathrm{C}$, and Kedzia and 
Kedzia [21], who suggested a temperature of $70-75^{\circ} \mathrm{C}$ and ideally under vacuum. The temperature used should not be too high, as it could lead to Maillard reactions that would affect both the taste and the nutritional composition of the product.

\subsubsection{Lyophilization}

Lyophilization of the honey bee drone brood was performed on freeze-drying system Alpha 1-4 LSC, Martin Christ Gefriertrocknungsanlagen GmbH, Osterode am Harz, Germany. The material was lyophilized at $-55{ }^{\circ} \mathrm{C}$ for $24 \mathrm{~h}$. The lyophilized bee drone brood was stored in closable plastic boxes in a freezer at $-18{ }^{\circ} \mathrm{C}$.

\subsection{Determination of the Elements}

The number of elements in the sample was identified using X-ray fluorescence (XRF) spectrometry analysis using an energy-dispersive (ED)-XRF Innov-X DELTA Handheld Spectrometer (Innov-X Systems, INC., Woburn, MA, USA), and the data were analyzed with DELTA Premium PC Software 97 (Innov-X Systems, INC.) according to Mlček et al. [22]. The ED-XRF Innov-X DELTA Spectrometer is a professional handheld spectrometer with a $40 \mathrm{kV}$ miniature $\mathrm{X}$-ray tube, Silicon Drift Detector, specialized filters, and multi-beam optimization.

Four samples $(n=4)$ were taken from the dried matter and homogenized in a DBO for analysis. The homogenized samples were placed into special measuring capsules (cylindrical in shape, diameter approximately $25 \mathrm{~mm}$, height approximately $15 \mathrm{~mm}$ ) and subsequently placed in a measuring box. Samples were measured 3 times. The measurement was performed automatically in the RoHS/WEEE mode (The Restriction of Hazardous Substances Directive (RoHS)/Waste Electrical and Electronic Equipment Directive (WEEE)). The maximum measurement time was set to $90 \mathrm{~s}$.

\subsection{Microbial Analysis}

Eight samples of dried homogenized DBO were taken for analysis. Four samples were analyzed immediately, whereas four were stored in a drying oven for 30 days at $25^{\circ} \mathrm{C}$ to allow the evaluation of the microbial composition changes of the samples over time.

For the determination of microbial contamination, $1 \mathrm{~g}$ of the dried DBO sample was taken, placed in a sterile tube, supplemented with $9 \mathrm{~mL}$ of sterile physiological saline solution, and centrifuged for $1 \mathrm{~min}$ [23].

For the determination of the total count of microorganisms (TMC), PCA broth (Biokar Diagnostics, Allonne, France) was used to cultivate for $72 \mathrm{~h}$ at $30{ }^{\circ} \mathrm{C}$. E. coli and other coliform bacteria were cultivated for $24 \mathrm{~h}$ on Rapid E. coli Agar (Bio-Rad, Hercules, CA, USA) at $37{ }^{\circ} \mathrm{C}$, and micromycetes were cultivated on Chloramphenicol Glucose Yeast Extract Agar (Biokar Diagnostics, Allonne, France) at $25^{\circ} \mathrm{C}$ for $120 \mathrm{~h}$. After cultivation, the number of typical colonies was evaluated, and the results were expressed in $\mathrm{CFU} / \mathrm{g}$ (colony-forming units in $1 \mathrm{~g}$ ) of the sample.

The above microbial analysis and elemental composition analysis were performed only on the DB material in order to present this raw material as safe (the safety of the raw material from the supplier was not guaranteed in this case) due to its further use in the nutritional ball.

\subsection{Preparing the Balls}

Dried drone brood, dried dates, dried apricots, dried plums, almonds, cashew nuts, lemon peel, and cinnamon were used for the production of balls. The ratios of the components of the balls, inspired by the formula in Oliver [24], are in Table 1. For comparison, balls with the same formula were also produced, but the dried drone brood was replaced with the same amount of oatmeal. From the values of the raw materials used in Table 2 and their ratios in the recipe (Table 1), the value of one ball (weight $10 \mathrm{~g}$ ) containing the dried drone brood (DBO-B) and one oatmeal ball $(\mathrm{O}-\mathrm{B})$ was calculated for comparison. $\mathrm{DB}$ 
nutritional values were determined according to NutriPro software, Fitsport-complex s.r.o., Židlochovice, Czech Republic; [g/100 g] were used for the calculation.

Table 1. Recipe for the production of balls with TP and oatmeal.

\begin{tabular}{ccc}
\hline \multirow{2}{*}{ Amount $[\mathrm{g}]$} & Balls with Dried TP & Balls with Oatmeal \\
\cline { 2 - 3 } & Ingredients & Ingredients \\
\hline 60 & drone brood dried at $80{ }^{\circ} \mathrm{C}$ & oatmeal \\
170 & almond & almond \\
150 & dried dates & dried dates \\
70 & dried apricots & dried apricots \\
70 & cashew nuts & cashew nuts \\
50 & dried plums & dried plums \\
& cinnamon & cinnamon \\
& lemon peel & lemon peel \\
\hline
\end{tabular}

Table 2. Nutritional values of the ingredients used for the making of the balls (according to software NutriPro, Fitsport-komplex s.r.o., Židlochovice, Czech Republic) [g/100 g in DM]. Nutritional value of the drone brood was calculated using the combination of the results of Ghosh et al. [7] and our results.

\begin{tabular}{cccccccc}
\hline $\begin{array}{c}\text { Nutritional } \\
\text { Components }\end{array}$ & $\begin{array}{c}\text { Dried Drone } \\
\text { Brood }\end{array}$ & Oatmeal & Almonds & Dates & Apricots & Cashew Nuts & Plums \\
\hline Protein $[\mathrm{g} / 100 \mathrm{~g}]$ & 40 & 13.1 & 21.2 & 1.9 & 4.5 & 18.2 & 2.6 \\
Fat $[\mathrm{g} / 100 \mathrm{~g}]$ & 20 & 6.9 & 49.4 & 0.5 & 0.5 & 43.8 & 0.7 \\
Carbohydrates $[\mathrm{g} / 100 \mathrm{~g}]$ & 35 & 68.1 & 21.6 & 66.3 & 67 & 30.2 & 2 \\
Fiber $[\mathrm{g} / 100 \mathrm{~g}]$ & 0.86 & 7.2 & 15 & 6 & 24 & 14 \\
Energy $[\mathrm{KJ} / 100 \mathrm{~g}]$ & 2017 & 1524 & 2406 & 1159 & 1219 & 2314 \\
\hline
\end{tabular}

Energy values of individual nutrients were also calculated using the conversion factors set out in Regulation (EU) No. 1169/2011 of the European Parliament and the Council [25]. The conversion factors for proteins and carbohydrates for fats are $17 \mathrm{KJ} / \mathrm{g}$ and $37 \mathrm{KJ} / \mathrm{g}$, respectively. After converting nutrients to percentages of energy value for both types of balls, the energy content of protein was $12.7 \%$ in the ball with the addition of $\mathrm{DB}$ and $10.4 \%$ in the ball with oatmeal. It was therefore possible to increase the percentage of energy value by almost $2.5 \%$ compared to oatmeal of the same amount by adding dry bee drone brood in an amount of about 10\%. Under Regulation (EU) No. 1924/2006 of the European Parliament and the Council [26] on nutrition and health claims made on foods, food with at least $12 \%$ protein energy value can be labeled as a source of protein. According to this claim, it is possible to label DBO balls as a source of protein, while a ball with oatmeal cannot be labeled as such.

\subsection{Sensory Analysis}

To determine the acceptability of dried DP products by potential consumers based on their sensory properties, a quantitative survey was conducted. The sensory evaluation was attended by students from Mendel University in Brno, Czech Republic. Respondents were randomly selected as volunteers among students aged 19-26 years in which gender differences were not considered the subject of the research. The evaluation was carried out in the framework of the practical training of the subject "Sensory Analysis of Foods" according to [27]. The sensory evaluations were performed as blind tests.

\subsubsection{Sensory Evaluation of the Dried Bee Drone Brood Sample}

The sensory evaluation of the dried bee drone brood sample was attended by a total of 40 respondents ( 5 men and 35 women). Before the sample evaluation, consumers were informed that there were samples of dried DB, one of which was lyophilized (DBL) and the 
other oven-dried (DBO). Students had the task to evaluate the odor, color, and taste of the two presented samples-one beaker contained DBL and the other DBO. In the evaluation, the respondents recorded the perception of the examined specimens on a $10 \mathrm{~cm}$ line. The values were then averaged and reported as a percentage. Based on the statement that these were insect samples, 4 respondents refused to participate in taste evaluation.

While evaluating taste, consumers also determined the intensity of partial flavors in the samples by choosing from the options offered. Using a scale of six degrees of intensity (1-imperceptible, 2-very weak, 3-quite weak, 4-moderately strong, 5-quite strong, 6-very strong), they evaluated the presence of a sweet, nutty, caramel, sharp, rancid, moldy, pungent, stale, bitter, and burnt taste.

\subsubsection{Sensory Evaluation of the Balls}

In this part of the sensory evaluation, a total of 42 respondents ( 5 men and 37 women) attended. One student did not evaluate the product with oatmeal completely because of a gluten allergy.

Students were informed of the environmental and nutritional benefits associated with edible insect consumption in general. Furthermore, the content of essential amino acids, iron, zinc, and vitamin $\mathrm{D}$ in the honey bee $\mathrm{DB}$, as well as information on common insect consumption on the African and Asian continents, and the availability of DB products in Romania and Ukraine were mentioned.

Then, two samples of fruit balls were presented to the respondents, one of which contained DB and the other oatmeal. The respondents rated the appearance, scent, taste, and juiciness in the enclosed form for both the samples. The respondents recorded the perception of the examined specimens on a $10 \mathrm{~cm}$ line. The values were then averaged and reported as a percentage.

Next, the respondents determined whether there was a difference between the samples. In such a case, they should indicate which of the samples they prefer. In a short questionnaire at the end of each sample, the students answered the following questions:

Question 1: Should the product be available on the market, would you buy it?

Question 2: If yes, would you buy it repeatedly/regularly?

Question 3: Would your decision to purchase this product be affected by the information you received before the evaluation?

\subsection{Statistical Analysis}

Excel 2013 (Microsoft Corporation, Redmond, WA, USA) and STATISTICA CZ version 12 (StatSoft, Inc., Tulsa, OK, USA) were used for data analysis. The results were expressed by the mean $(\mathrm{M}) \pm$ standard deviation (SD).

Due to the non-compliance with the prerequisites for the ANOVA type statistical evaluation in many cases, the Kruskal-Wallis test had to be applied to compare the obtained data $(\alpha=0.05)$. Closed questions in questionnaires with only two possible answers were evaluated using Fisher's exact two-tailed test $(\alpha=0.05)$. A difference between the oatmeal ball (O-B) and the DBO ball (DBO-B) was evaluated by a paired comparison test $(\alpha=0.01)$.

\section{Results}

\subsection{Mineral Content}

The results from the XRF spectrometry analysis of the DB samples are presented in Table 3. In the sample, high values of calcium, iron, and zinc were expected, based on the available information. Relatively high values of calcium, iron, zinc, and copper were detected in the sample. The presence of cadmium and mercury was not found. A relatively high silver content of $82.7 \mu \mathrm{g} / \mathrm{g}$ was detected and $1.2 \mu \mathrm{g} / \mathrm{g}$ of gold was also detected. Furthermore, a high content of lead was detected in the sample- $-2.1 \mu \mathrm{g} / \mathrm{g}$.

Table 3 also shows the Population Reference Intake (PRIs) and Tolerable upper intake level (UL), which are taken from the Dietary Reference Values database for the EU, EFSA (adult male). 
Table 3. Elements detected in the DBO sample $(n=4)$. Values are presented as average $(\mathrm{M})$ and standard deviation (SD). Values PRIs/UL presenting population reference intake (PRI) and tolerable upper intake level (UL).

\begin{tabular}{|c|c|c|c|c|c|c|c|}
\hline Elements & $\begin{array}{c}\mathbf{M} \\
{[\mu \mathrm{g} / \mathrm{g}]}\end{array}$ & $\begin{array}{c}\text { SD } \\
{[\mu \mathrm{g} / \mathrm{g}]}\end{array}$ & $\begin{array}{l}\text { PRIs/UL } \\
\text { [mg/day] }\end{array}$ & Elements & $\begin{array}{c}\mathbf{M} \\
{[\mu \mathrm{g} / \mathrm{g}]}\end{array}$ & $\begin{array}{c}\text { SD } \\
{[\mu \mathrm{g} / \mathrm{g}]}\end{array}$ & $\begin{array}{l}\text { PRIs/UL } \\
\text { [mg/day] }\end{array}$ \\
\hline $\mathrm{Cl}$ & ND & & $3.1 *$ & Mo & 4.5 & 1.17 & NA/0.6 \\
\hline $\mathrm{Ca}$ & 1336 & 154.67 & $1000 / 2500$ & $\mathrm{Ag}$ & 82.7 & 9 & \\
\hline $\mathrm{Cr}$ & ND & & & $\mathrm{Cd}$ & ND & & \\
\hline $\mathrm{Fe}$ & 60.87 & 6.33 & $11 / N D$ & $\mathrm{Hg}$ & ND & & \\
\hline $\mathrm{Cu}$ & 54.83 & 5 & $\mathrm{NA} / 5$ & $\mathrm{~Pb}$ & 2.1 & 1 & \\
\hline $\mathrm{Zn}$ & 257 & 7 & $9.4-16.3 / 25$ & $\mathrm{Bi}$ & 3.87 & 1.1 & \\
\hline $\mathrm{Br}$ & 1.95 & 0.4 & & $\mathrm{Mn}$ & 0 & 0 & NA/ND \\
\hline $\mathrm{Sr}$ & 3.13 & 0.73 & & Sn & 0 & 0 & \\
\hline $\mathrm{Zr}$ & 1.67 & 0.37 & & $\mathrm{Au}$ & 1.2 & 0.37 & \\
\hline
\end{tabular}

Note: ND = element not detected (in column M); 0 = sample contained a concentration of element below the level of determination; ${ }^{*}=$ safe and adequate intake; NA = not applicable (in column PRIs/UL); ND = not defined (in column PRIs/UL).

\subsection{Microbiological Evaluation of the DBO Sample}

In the first batch of microbial analysis (Table 4), the TMC content was highest, while the content of yeast and fungi was lower. The value was $9.6 \times 10^{2} \mathrm{CFU} / \mathrm{g}$. The TMC content in the sample became more than doubled after one month of storage. On the other hand, the amount of yeast decreased more than eight times, and the amount of mold decreased by about a third. None of the samples showed the presence of E. coli or other coliform bacteria.

Table 4. Microbiological analysis (in colony-forming units in $1 \mathrm{~g}$ ) of the DBO sample at the beginning of storage (Analysis I) and after one month (Analysis II).

\begin{tabular}{ccccc}
\hline Analysis & $\begin{array}{c}\text { E. coli/Other } \\
\text { Coliform Bacteria }\end{array}$ & TMC & Yeasts & Molds \\
\hline I. & $0 / 0$ & $9.6 \times 10^{2}$ & $4.1 \times 10^{1}$ & $1.3 \times 10^{2}$ \\
II. & $0 / 0$ & $2.2 \times 10^{3}$ & $5.0 \times 10^{0}$ & $8.2 \times 10^{1}$ \\
\hline
\end{tabular}

Abbreviations: E. coli.-Escherichia coli; TMC—-total count of microorganisms.

\subsection{Sensory Analysis Evaluation}

\subsubsection{Sensory Analysis of the Dried Bee Drone Brood Sample}

The results of the sensory analysis of the drone brood sample (lyophilized drone brood and drone brood dried in the oven) are shown in Table 5. The results show that, except for color, the lyophilized bee drone brood was more pleasing to the evaluators. A statistically significant difference (Kruskal-Wallis test) was only found for taste $(p<0.05)$.

Table 5. Sensory evaluation of the dried drone brood samples.

\begin{tabular}{cccc}
\hline Sample & Odor & Color & Taste \\
\hline lyophilized drone brood & $64 \% \pm 23 \%$ & $27 \% \pm 19 \%$ & $80 \% \pm 20 \% *$ \\
drone brood dried in oven & $59 \% \pm 24 \%$ & $39 \% \pm 21 \%$ & $57 \% \pm 24 \% *$ \\
\hline
\end{tabular}

Note: * Statistically significant difference (Kruskal-Wallis test, $p<0.05$ ); the 42 respondents participated in sensory evaluation.

The 42 respondents also assessed the presence of some partial flavors and their intensity in the samples (Figure 2). The average values $(M \pm S D)$ of all the flavors shown in the graph show that the DBO had a significantly more intense nutty, caramel, and burnt taste than the DBL ball. For the oatmeal ball, a stale taste was evaluated as more intense. A smaller difference in intensity was observed in sharp and bitter taste, which was marked 
as more intense in the DB ball, and a rancid taste in the oatmeal ball. For the other partial flavors, the intensity was more or less balanced.

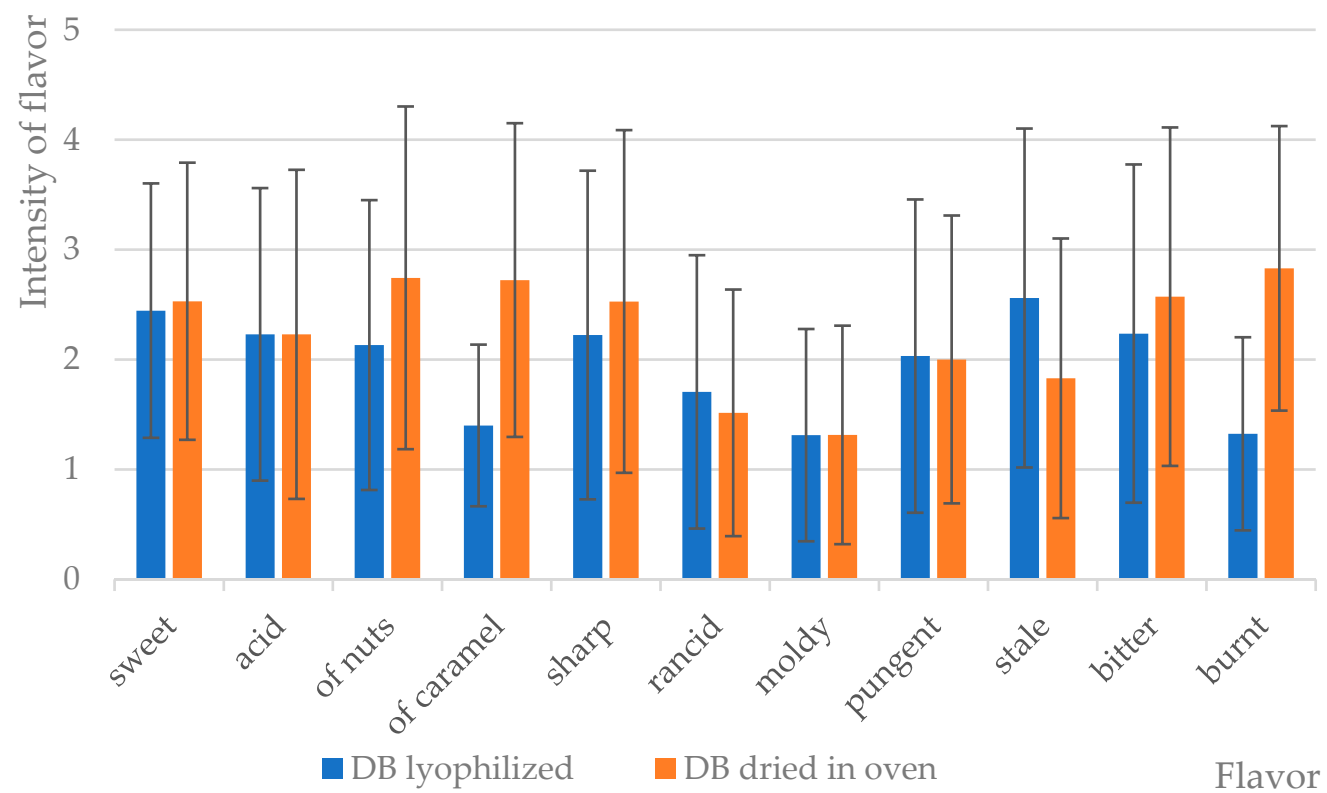

Figure 2. The average values $(\mathrm{M} \pm \mathrm{SD}$ ) of the intensity of the flavor (level: 1-imperceptible, 2-very weak, 3-quite weak, 4-moderately strong, 5-quite strong, 6-very strong).

\subsubsection{Sensory Analysis of Balls}

The difference between the taste of the oatmeal ball (O-B) and the DBO ball (DBO-B) was reported by $80 \%$ of students and was confirmed by a paired comparison test $(p<0.01)$.

Of the respondents who reported that there was a difference between the samples, $79 \%$ preferred the oatmeal ball $(p<0.01)$. The $\mathrm{O}-\mathrm{B}$ oatmeal ball preference is also evident from the graphical representation of the consistency, scent, taste, and juiciness of both samples (Figure 3). Except for the juiciness of the product, consumers rated the oatmeal ball as better. A statistically significant difference (Kruskal-Wallis test, $p<0.05$ ) was found only in taste.

Respondents then completed a short questionnaire, the results of which are shown in Figure 4. Students were willing to try both products, but they preferred the O-B more (Fisher's exact test, $p<0.05$ ). Almost $79 \%$ of the respondents stated that the information obtained before the evaluation influenced them in their decision making but were significantly less likely to buy the insect product a second time than the oatmeal balls (Fisher's exact test, $p<0.05)$. 


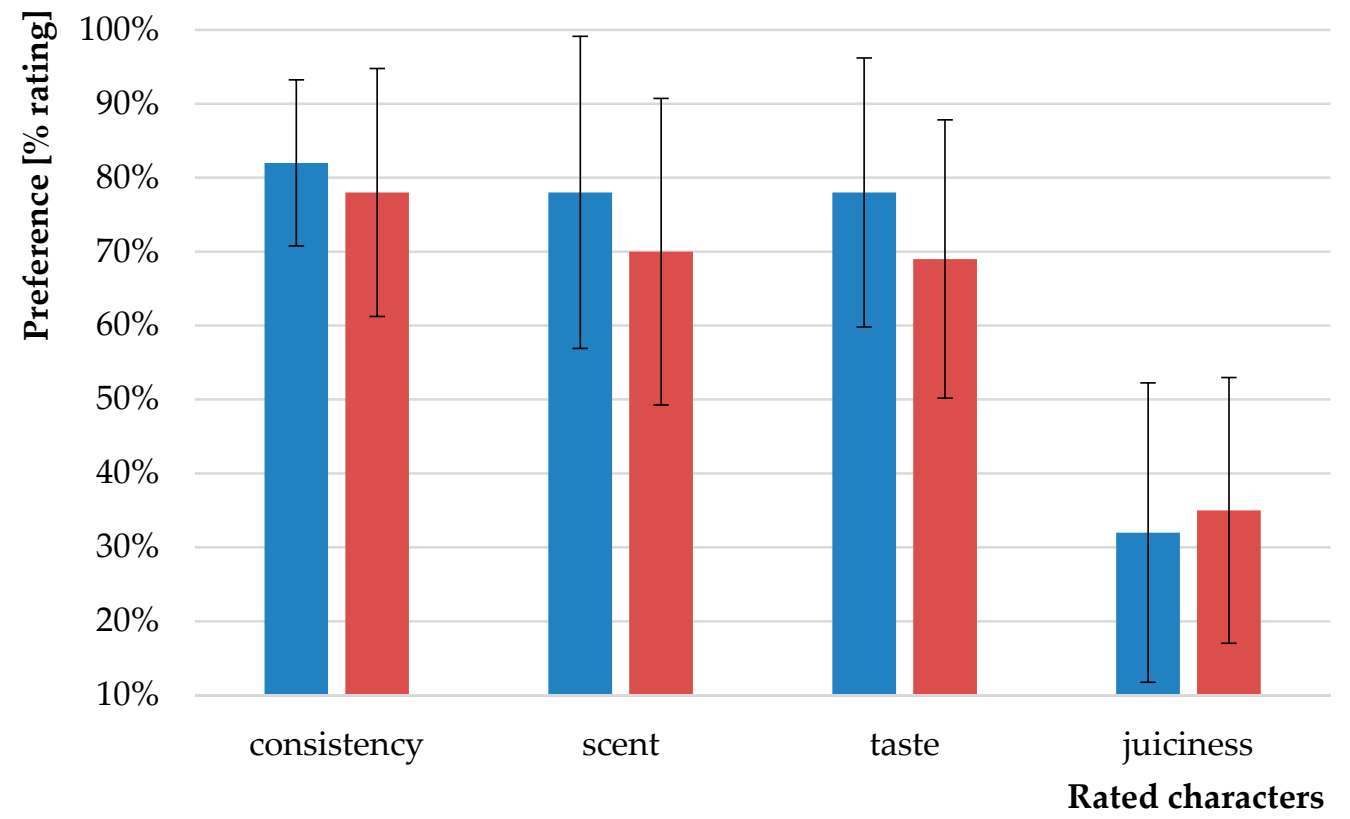

Figure 3. Comparison of the evaluated properties of oatmeal balls (O-B; blue color) and DBO balls (DB-B; red color).

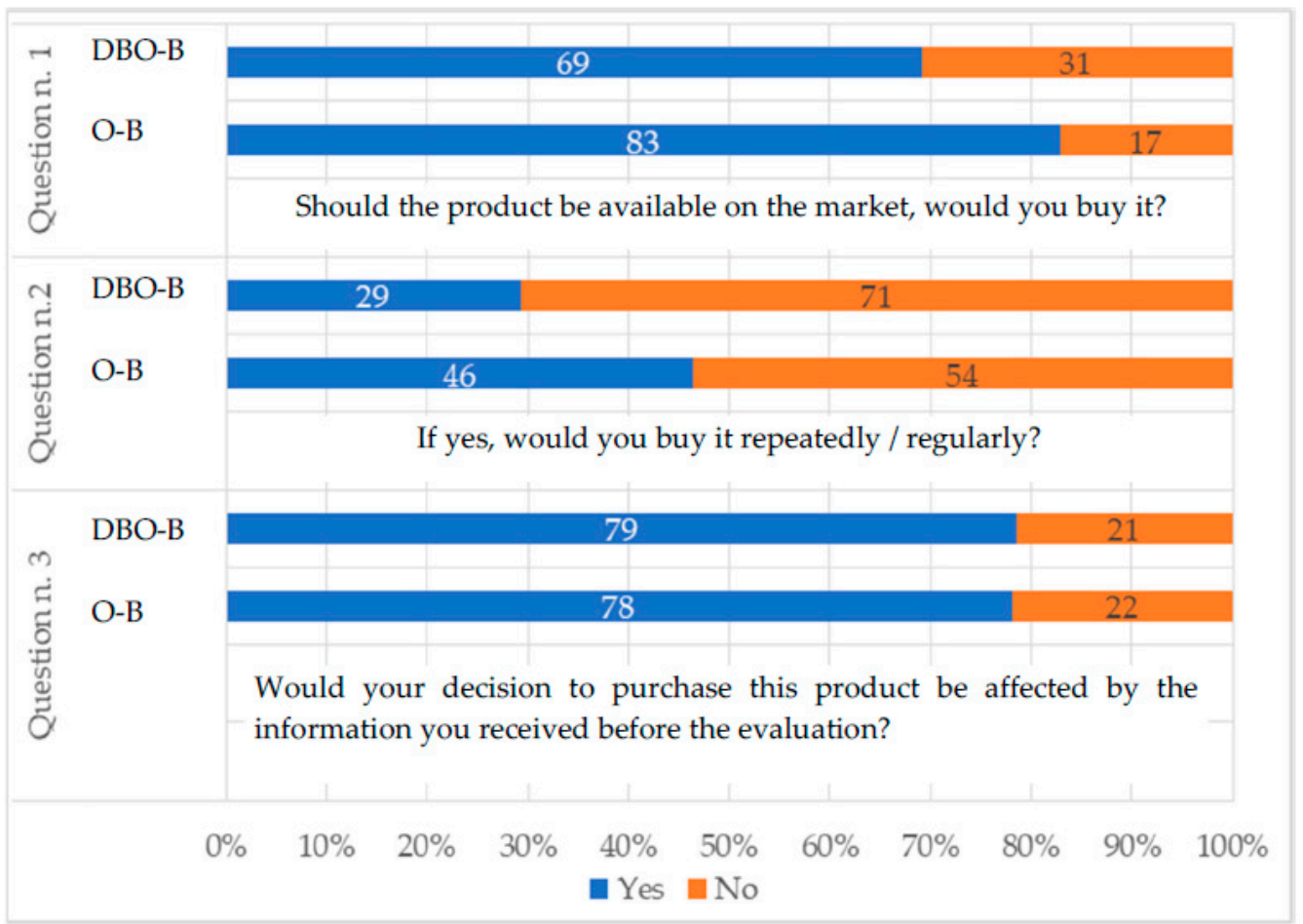

Figure 4. Graph showing respondents' answers to questions about oatmeal balls (O-B) and DBO balls (DBO-B).

\section{Discussion}

\subsection{Determination of Element Content}

Ghosh et al. [7] reported calcium content of $849 \mu \mathrm{g} / \mathrm{g}$ in larvae dry matter and $970 \mu \mathrm{g} / \mathrm{g}$ in pupae as well as an iron content of $133 \mu \mathrm{g} / \mathrm{g}$ in larvae and $153 \mu \mathrm{g} / \mathrm{g}$ in pupae. Zinc values were $116 \mu \mathrm{g} / \mathrm{g}$ for larvae and $117 \mu \mathrm{g} / \mathrm{g}$ for pupae. The reference described the sample preparation as follows: dried sample (at $100{ }^{\circ} \mathrm{C}$ ) was digested with nitric acid and hydrochloric acid at $200{ }^{\circ} \mathrm{C}$ for $30 \mathrm{~min}$ and subsequently filtered. Then the sample 
was analyzed using an inductively induced plasma optical emission spectrometer. When comparing these results with ours, zinc was twice as high and iron twice as low in our measurements. Chen et al. [28] reported a calcium content of $5 \mu \mathrm{g} / \mathrm{g}$, iron $18.9 \mu \mathrm{g} / \mathrm{g}$, and zinc $10.5 \mu \mathrm{g} / \mathrm{g}$ in fresh larvae. If the content of dry matter, which is not mentioned by the reference, would be $20 \%$, the calcium and zinc values would be much lower and the content higher compared to that of our results. Banjo et al. [5] report that the calcium content $(154 \mu \mathrm{g} / \mathrm{g})$ was much lower and the iron content $(252 \mu \mathrm{g} / \mathrm{g})$ much higher than in our samples. The differences may be caused by food, season, or analytical methods; however, this was not a subject of our research.

Velemínský et al. [29] determined the metal content in honey bee products in the Czech Republic using atomic absorption spectrometry. In the dry matter of drone larvae, they detected a concentration of $0.04 \mu \mathrm{g} / \mathrm{g}$ for cadmium, $0.1 \mu \mathrm{g} / \mathrm{g}$ for lead, and $29.48 \mu \mathrm{g} / \mathrm{g}$ for copper. Madras-Majewska and Jasinski [30] documented the lead content of brood in the different regions of Poland from 0.013 to $0.030 \mu \mathrm{g} / \mathrm{g}$. Heavy metals and other elements were also determined by Al Naggar et al. (2013) [31]. Dried bee samples were left in nitric acid $\left(\mathrm{HNO}_{3}\right)$ for $2 \mathrm{~h}$ at $65{ }^{\circ} \mathrm{C}$. The heavy metal content of the filtrate of this sample was analyzed by FAAS (flame atomic absorption spectrometry). The copper content (average of several samples) was $15 \mu \mathrm{g} / \mathrm{g}$, the cadmium content $1 \mu \mathrm{g} / \mathrm{g}$, and the lead content $10 \mu \mathrm{g} / \mathrm{g}$.

In their work, Al Naggar et al. also found that the content of these metals in bees was noticeably higher in spring than in summer and that the content in bees was higher than in bee products (honey, pollen). The composition of the drone offspring is therefore very variable. The accumulation of heavy metals and other elements in various insect species has already been confirmed and usually depends on the level of pollution in the environment.

Totals of $82.7 \mu \mathrm{g} / \mathrm{g}$ silver and $1.2 \mu \mathrm{g} / \mathrm{g}$ gold were found in our DBO samples. The presence of cadmium and mercury was not detected, but the observed value of lead content in dry matter $(2.1 \mu \mathrm{g} / \mathrm{g})$ was high and significantly exceeded, for example, the limit set by Commission Regulation (EC) No. 1881/2006 for crustaceans (0.4 $\mu \mathrm{g} / \mathrm{g}$ ) [32]. Because the drone brood used in our research came from an industrial area, high heavy metal limits could have been the cause behind this factor, similar to [33,34]. This was contrary to another document [35], which identified the drone brood as a toxicologically safe raw material.

\subsection{Microbiological Evaluation of the DBO Sample}

According to Commission Regulation (EC) No. 2073/2005, the main source of human food-related diseases is the microbial hazard [36]. For this reason, foods should not contain microorganisms or their toxins or metabolites in quantities that pose a risk to human health. Since no microbial limits for edible insects have been established yet, the measured values are often compared with food safety criteria in Commission Regulation (EC) No. 2073/2005 to produce cooked crustaceans and mollusks, as the taste of insects is often compared to that of crustaceans [36]. According to this regulation, the absence of microorganism Salmonella spp., its toxin, or metabolite in a $25 \mathrm{~g}$ sample must be confirmed (the limit is 0 ) in the case of crustaceans. Since this work did not address the presence of Salmonella, it is not possible to determine whether the DB meets this limit. The results can be compared with the limit values given in CSN 56 9609:2008, which are determined for the total number of microorganisms as $10^{5} \mathrm{CFU} / \mathrm{g}$ and Escherichia coli $5 \times 10^{5}$ [37].

In other species of edible insects, Adámek et al. [38] listed the TMC content of Tenebrio molitor at $5.4 \times 10^{3} \mathrm{CFU} / \mathrm{g}$, Gryllus assimilis (nymphs) at $7.1 \times 10^{3} \mathrm{CFU} / \mathrm{g}$, and Locusta migratoria (adult) at $3 \times 10^{3} \mathrm{CFU} / \mathrm{g}$ in dried specimens. Coliform bacteria were not detected in these species, and yeasts and molds were measured at $1.5 \times 10^{3} \mathrm{CFU} / \mathrm{g}$ in Tenebrio molitor, $6 \times 10^{3} \mathrm{CFU} / \mathrm{g}$ in Gryllus assimilis, and $2.6 \times 10^{3} \mathrm{CFU} / \mathrm{g}$ in Locusta migratoria. In comparison to this work, the values of DBO TCM contamination, yeasts, and molds found by us were lower, even after 30 days of storage. Dried DB is microbially harmless in this regard, as it meets the limit for TMC and E. coli. 


\subsection{Sensory Analysis Evaluation}

\subsubsection{Sensory Analysis of the Dried DBO Sample}

It can be concluded from the evaluated results of the dried bee drone brood sample that the drying process had some effect on the scent, appearance, and taste of the final product. The taste of sweetness, acidity, sharpness, or bitterness of the two samples was balanced, which could mean that they are typical for the DB. Oven-drying led to a greater intensity of nutty, caramel, or burnt taste. Although the lyophilization of the sample intensified the stale taste, respondents still rated it as better over the oven-dried samples. There was also a statistically significant difference $(p<0.05)$ in taste in contrast to scent and color. In the lyophilized sample, respondents also reported better odor. Compared to the oven-dried sample, however, the respondents did not like the color of the lyophilized sample.

\subsubsection{Sensory Analysis of Balls}

In the sensory analysis of balls, students preferred oatmeal nutrition balls. When compared to the sample with DB, students rated consistency, aroma, and taste as better. There was also a statistically significant difference in taste. However, the juiciness was rated as better in DB balls. Furthermore, there are cultures in the world that have been consuming insects for thousands of years.

Before the sensory analysis, we talked about the environmental and nutritional benefits with the respondents, to explain the reason for this research. Nevertheless, the reserved attitude of the respondents to DBO balls prevailed in the questionnaire survey. Similarly, Cossar [39] describes in his article how "disgusting and gross" insects are for the European population. Despite the gradual change in the European public's view of the issue of edible insects, a large part of the population is averse to edible insects or ranks it among experiential gastronomy. However, there are cultures in the world that have been consuming insects for thousands of years [40].

In addition, eating habits are not ideal worldwide; for example, in Central Europe, a high content of carbohydrates and fats in the diet still prevails [41,42]. Because DBs contain enough protein and fit into a balanced diet, enriching the diet with DB would be a good step toward a better diet from a dietary point of view.

\section{Conclusions}

We consider the high level of lead found to be a significant finding, due to which bee drone brood cannot be considered as a safe food ingredient. The question is whether the high $\mathrm{Pb}$ content is due to contamination caused by the presence of such metal in the sampling environment or due to the ability of the drone brood to accumulate lead. There is a need for further research into this commodity, which is commonly referred to in the literature as safe and nutritionally rich.

The food industry is looking for protein sources that could meet the recommendations of the European Food and Nutrition Action Plan 2015-2020 [43]. One such source could be DB if it would meet the requirements for safe food and would be accepted by the consumer.

Based on the research, the established hypotheses must be rejected.

Regarding the microbial load, the content of dangerous bacteria in our sample was well below the required values, even after 30 days of storage at $25^{\circ} \mathrm{C}$. However, the high $\mathrm{Pb}$ values found in $\mathrm{DB}$ dry matter $(2.1 \mu \mathrm{g} / \mathrm{g})$ do not allow DB to be considered a safe food ingredient.

The high content of lead and silver may be caused by the fact that the drone brood used in our research came from an industrial area. Opinions on drone brood toxicity (heavy metals) are not uniform in the literature. Therefore, there is a need for further research into the bioaccumulation of lead in the food chain and the developmental cycle of honey bees in various industrial areas. Only then would it be possible to consider the use of drone brood in the food industry at all, or only from certain areas. The possible high contamination could also mean that practical use of drone brood as a food component would require mandatory analysis of every batch of drone brood. 
The results of sensory analysis show that respondents statistically significantly prefer the tested O-B over DBO-B (Fisher's exact test, $p<0.05$ ). Furthermore, they statistically significantly prefer the taste of DBL over DBO $(p<0.05)$.

The taste of DB products is crucial here. Potential producers will have to look for ways to improve the appetite of their products. One way is perhaps to use DBL instead of dried DB.

Author Contributions: Conceptualization, J.M.; methodology, Z.M.; software, M.A.; validation, M.B. (Martina Bednářová) and V.Š.; formal analysis, Z.M. and M.A.; resources, M.B. (Marie Borkovcová); writing-original draft preparation, Z.M. and J.M.; writing—review and editing, A.A.; supervision, J.M. All authors have read and agreed to the published version of the manuscript.

Funding: This article was supported by the internal grant of TBU in Zlín (No. IGA/FT/2022/004) and project BUT in Brno (FEKT-S-20-6215).

Institutional Review Board Statement: Not applicable.

Informed Consent Statement: Not applicable.

Data Availability Statement: New research data were presented in this contribution.

Conflicts of Interest: The authors declare no conflict of interest.

\section{References}

1. Premalatha, M.; Abbasi, T.; Abbasi, T.; Abbasi, S.A. Energy-efficient food production to reduce global warming and ecodegradation: The use of edible insects. Renew. Sust. Energ. Rev. 2011, 15, 4357-4360. [CrossRef]

2. FAO. Edible Insects: Future Prospects for Food and Feed Security; FAO: Rome, Italy, 2013; 187p. Available online: https://www.fao. org/3/i3253e/i3253e00.htm (accessed on 20 February 2022).

3. Simakovič, N.N.; Belaruski, P. “Okřídlení farmaceuti” dávají mužům sílu (“Winged pharmacists” give men strength). Odborné Včelařské Překlady (Prof. Beekeep. Transl.) 2016, 2, 1-5.

4. Kulhánek, Z. Tube milk-elixir for men. Vcelarstvi 2016, 7, 243.

5. Banjo, A.D.; Lawall, O.A.; Songonuga, E.A. The nutritional value of fourteen species of edible insects in southwestern Nigeria. Afr. J. Biotechnol. 2006, 5, 298-301.

6. Payne, C.L.R.; Scarborough, P.; Rayner, M.; Nonaka, K. A systematic review of nutrient composition data available for twelve commercially available edible insects, and comparison with reference values. Trends Food Sci. Technol. 2016, 47, 69-77. [CrossRef]

7. Ghosh, S.; Jung, C.; Meyer-Rochow, V.B. Nutritional value and chemical composition of larvae, pupae, and adults of worker honey, Apis mellifera ligustica as a sustainable food source. J. Asia Pac. Entomol. 2016, 19, 487-495. [CrossRef]

8. Finke, M.D. Nutrient Content of Insects. In Encyclopedia of Entomology; Kluwer Academic Publishers: Dordtrecht, The Netherlands, 2004; pp. 1563-1575.

9. Ozimek, L.; Sauer, W.C.; Kozikowski, V.; Ryan, J.K.; Jorgensen, H.; Jelen, P. Nutritive Value of Protein Extracted from Honey bees. J. Food Sci. 1985, 50, 1327-1329. [CrossRef]

10. Shewry, P.R. Improving the protein content and composition of cereal grain. J. Cereal Sci. 2007, 46, 239-250. [CrossRef]

11. Rumpold, B.A.; Schlüter, O.K. Nutritional composition and safety aspects of edible insects. Mol. Nutr. Food Res. 2013, 57, 802-823. [CrossRef]

12. Aumeier, P.; Boecking, O.; Liebig, G. Drohnen schneiden mit Systém. Dtsch. Bienen J. 2009, 17, 156-157. Available online: https://www.bienen-ag.ch/fileadmin/Sektionen/Unteres-Aaretal/Drohnenbrut_schneiden.pdf (accessed on 20 February 2022).

13. Lecocq, A.; Foley, K.; Jensen, A.B. Done brood production in Danish apiaries and its potential for human consumption. J. Apic. Res. 2018, 57, 331-336. [CrossRef]

14. Dohnal, F.; Smejkal, F. Pěstování Moruší a Chov Bource Morušového (In Czech, Mulberry Cultivation and Silkworm Rearing); Beekeeping Research Institute: Máslovice, Czech Republic, 1993.

15. Pagač, M. Z historie hedvábnictví v Čechách a na Moravě (in Czech, From the history of silking in Bohemia and Moravia). Vcelarstvi 1993, 46, 80.

16. Veselý, V. Včelařský výzkum a hedvábnictví (Beekeeping research and silk). Vcelarstvi 1993, 46, 195.

17. Durst, B.P.; Johnson, D.V.; Leslie, R.N.; Shono, K. Forest Insects as Food: Humans Bite Back; Food and Agriculture Organization of the United Nations: Bangkok, Thailand, 2010; Available online: http:/ /www.fao.org/3/a-i1380e.pdf (accessed on 23 May 2019).

18. EFSA. Risk profile related to production and consumption of insects as food and feed. EFSA J. 2015, 13, 4257. [CrossRef]

19. Stoops, J.; Cauwels, S.; Waud, M.; Claes, J.; Lievens, J.; Van Campenhout, L. Microbial community assessment of mealworm larvae (Tenebrio mollitor) and grasshoppers (Locusta migratoria migratorioides) sold for human consumption. Food Microbiol. 2016, 53, 122-127. [CrossRef] [PubMed]

20. Klunder, H.C.; Wolkers-Rooijackers, J.; Korpela, J.M.; Nout, M.J. Microbiological aspects of processing and storage of edible insects. Food Control 2012, 26, 628-631. [CrossRef] 
21. Kedzia, B.; Kedzia, E. Bee brood as a therapeutic substance. Pszczelarstwo 2015, 6, 5-6.

22. Mlček, J.; Adámek, M.; Adámková, A.; Borkovcová, M.; Bednářová, M.; Skácel, J. Detection of selected heavy metals and micronutrients in edible insect and their dependency on the feed using XRF spectrometry. Potravin. Slovak J. Food Sci. 2017, 11, 725-730. [CrossRef]

23. Šilhánková, L. Mikrobiologie pro Potravináře a Biotechnology (Microbiology for Food Producers and Biotechnologists); Academia: Praha, Czech Republic, 2002; 363p.

24. Oliver, J. Everyday Super Food; Penguin Books: London, UK, 2015.

25. Regulation (EC) No. 1169/2011 of the European Parliament and of the Council of 25 October 2011 on the Provision of Food Information to Consumers Amending Regulation (EC) No 1924/2006 of the European Parliament and of the Council (EC) No 1925/2006 and repealing Commission Directive 87/250/EEC, Council Directive 90/496/EEC, Commission Directive 1999/10/EC, Directive 2000/13/EC of the European Parliament and of the Council, Commission Directives 2002/67/EC and 2008/5/EC and Commission Regulation (EC) No 608/2004. Official Journal of the European Union 304/18. Available online: https: / / eur-lex.europa.eu/legal-content/CS/TXT/?uri=celex\%3A32011R1169 (accessed on 11 May 2019).

26. Regulation (EC) No. 1924/2006 of the European Parliament and of the Council of 20 December 2006 on Nutrition and Health Claims Made on Foods. Official Journal of the European Union 404/9. Available online: https:/ / eur-lex.europa.eu/legal-content/ CS/TXT/PDF/?uri=CELEX:32006R1924\&from=EN (accessed on 11 May 2019).

27. Pokorný, J. Methods of Sensory Analysis of Food and Determination of Sensory Quality, 2nd ed.; Institute of Agricultural Economics and Information: Prague, Czech Republic, 1993; p. 196.

28. Chen, P.P.; Wongsiri, S.; Jamyanya, T.; Rinderer, T.E.; Vongsamanode, S.; Matsuka, M.; Sylvester, H.A.; Oldroyd, P.B. Honey bees and Other Edible Insects Used as Human Food in Thailand. Am. Entomol. 1998, 44, 24-29. [CrossRef]

29. Velemínský, M.; Láznička, P.; Starý, P. Honey bees (Apis mellifera) as environmental monitors of heavy metals. Acta Enthomol. Bohemoslov. 1990, 87, 37-44.

30. Madras-Majewska, B.; Jasinski, Z. Lead content of bees, brood and bee products from different regions of Poland. J. Apic. Sci. 2003, 47, 47-55.

31. Al Naggar, Y.A.; Naiem, E.-S.A.; Seif, A.I. Honey bees and their products as a bio-indicator of environmental pollution with heavy metals. Mellifera 2013, 13, 10-20.

32. Regulation (EC) No. 1881/2006 of 19 December 2006 Setting Maximum Levels for Certain Contaminants in Foodstuffs. Official Journal of the European Union 364/5. Available online: https:/ / eur-lex.europa.eu/LexUriServ/LexUriServ.do?uri=OJ:L:2006: 364:0005:0024:CS:PDF (accessed on 11 May 2019).

33. Zarić, N.M.; Ilijević, K.; Stanisavljević, L.; Gržetić, I. Metal concentrations around thermal power plants, rural and urban areas using honeybees (Apis mellifera L.) as bioindicators. Int. J. Environ. Sci. Technol. 2016, 13, 413-422. [CrossRef]

34. Borg, D.; Attard, E. Honeybees and their products as bioindicators for heavy metal pollution in Malta. Acta Brasiliensis. 2020, 4 , 60-69. [CrossRef]

35. Summary of the Dossier: Honey bee Drone Brood (Apis mellifera Male Pupae). Available online: https://ec.europa.eu/food/ sites/food/files/safety/docs/novel-food_sum_ongoing-app_2018-0754.pdf (accessed on 30 May 2020).

36. Regulation (EC) No. 2073/2005 of 15 November 2005 on Microbiological Criteria for Foodstuffs. OJ L 338/1. pp. 1-26. Available online: https:/ / eur-lex.europa.eu/legal-content/EN/ALL/?uri=CELEX\%3A32005R2073 (accessed on 11 May 2019 ).

37. CSN 56 9609:2008; Rules of Good Hygienic and Production Practice-Microbiological Rules for Food. Principle of Determination and Application, Czech Technical Standard. Czech Standards Institute: Prague, Czech Republic, 2008.

38. Adámek, M.; Mlček, J.; Adámková, A.; Suchánková, J.; Janalíková, M.; Borkovcová, M.; Bednářová, M. Effect of different storage conditions on the microbiological characteristics of insect. Potravin. Slovak J. Food Sci. 2018, 12, 248-253. [CrossRef]

39. Cossar, V.-M. Could Insects Soon Form Part of Our Regular Diet? 2012. Available online: https://metro.co.uk/2012/12/17 / could-insects-soon-form-part-of-our-regular-diet-3318502/ (accessed on 2 February 2022).

40. FAO. Looking at Edible Insects from a Food Safety Perspective. Challenges and Opportunities for the Sector; FAO: Rome, Italy, 2021; 108p Available online: https:/ / www.fao.org/documents/card/en/c/cb4094en (accessed on 2 February 2022).

41. Fořt, P. Co Jime a Pijeme: Výživa pro 3. Tisíciletí; What We Eat and Drink: Nutrition for the 3rd Millennium; Olympia: Praha, Czech Republic, 2003. (In Czech)

42. WHO. The Challenge of Obesity in the WHO European Region and the Strategies for Response: Summary; Branca, F., Nikogosian, H., Lobstein, T., Eds.; WHO Regional Office for Europe: Copenhagen, Denmark, 2007; 60p, Available online: https:/ /www.euro. who.int/en/publications / abstracts/challenge-of-obesity-in-the-who-european-region-and-the-strategies-for-response-the. -summary (accessed on 2 February 2022).

43. World Health Organization; Regional Office for Europe. European Food and Nutrition Action Plan 2015-2020. 2015. Available online: https:/ / apps.who.int/iris/handle/10665/329405 (accessed on 11 May 2020). 